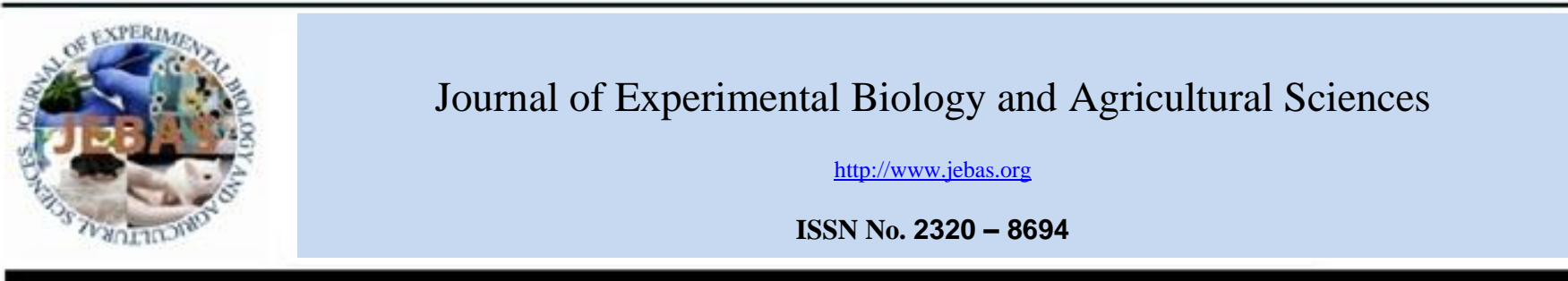

\title{
A STUDY ON THE EFFECT OF CINNAMON AND CINNAMALDEHYDE ON BOVINE SERUM ALBUMIN (BSA) PROTEIN BY USING FT-RAMAN SPECTROSCOPY
}

\author{
Kamal Alhammad ${ }^{* \#}$, Nazlin Howell
}

Faculty of Health and Medical Sciences, University of Surrey, Guildford, Surrey GU2 7XH, UK

Received - May 26, 2018; Revision - July 28, 2018; Accepted - August 09, 2018

Available Online - August 10, 2018

DOI: http://dx.doi.org/10.18006/2018.6(4).677.683

\author{
KEYWORDS \\ Cinnamon \\ Cinnamaldehyde \\ Bovine serum albumin (BSA) \\ FT-Raman spectroscopy
}

\begin{abstract}
FT-Raman spectroscopy revealed comparative intensity changes of many bands and wave number shifts, when comparing bovine serum albumin (BSA) separately, BSA mixed with $500 \mathrm{ppm}$ cinnamaldehyde and BSA mixed with 500 ppm cinnamon. It is clear that there are small shifts in wave numbers. The intensity of tryptophan band at $760 \pm 2 \mathrm{~cm}^{-1}$ was $0.42 \pm 0.02$; there was no significant difference between the value for BSA alone and BSA + cinnamon sample $(0.433 \pm 0.081)$. In contrast, in sample BSA + cinnamaldehyde the tryptophan band intensity $(0.296 \pm 0.066)$ significantly decreased $(\mathrm{p}<0.05)$. The decrease was ascribed to Trp vibrational modes and $\mathrm{C}-\mathrm{H}$ bending due to the enhancement of hydrophobic residues open to the outer surface of proteins. This result can be used to monitor denaturation in protein aliphatic and aromatic side chains. The decrease in the tyrosine ratio $855 / 830 \mathrm{~cm}^{-1}$ of the BSA mixture with cinnamon and cinnamaldehyde separately, compared to BSA alone, was attributed to strong hydrogen bonding interactions in the mixture involving tyrosine residues.
\end{abstract}

* Corresponding author

E-mail: Abusaad_28@hotmail.com (K. Alhammad)

\# Present address: Department of Nutrition, Prince Sultan Military Medical City, Riyadh, Kingdom of Saudi Arabia

Peer review under responsibility of Journal of Experimental Biology and Agricultural Sciences.

Production and Hosting by Horizon Publisher India [HPI] (http://www.horizonpublisherindia.in/).

All rights reserved.
All the article published by Journal of Experimental Biology and Agricultural Sciences is licensed under a Creative Commons Attribution-NonCommercial 4.0 International License Based on a work at www.jebas.org.

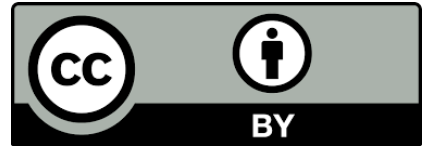




\section{Introduction}

Proteins are significant functional polymers that are widely used in biochemical, pharmaceutical and food applications (Damodaran, 1996). The alteration of proteins via lipid peroxidation products, together with free radicals and aldehydes, has been thoroughly studied (Uchida, 2003; Ozeki et al., 2005). The product that results from aldehyde lipid oxidation causes a strange flavour, a rancid odour and the discoloration of meat (Fogetty et al., 1989). Lipid peroxidation releases high amounts of various by-products (Paliyath et al., 2011), such as malondialdehyde, and bioactive $\alpha, \beta$ unsaturated aldehydes, including 4-hydroxy-2-trans-nonenal and hydroxynonenal, are regularly considered to be indicators of in vivo oxidative stress (Refsgaard et al., 2000). However, Ulberth \& Roubicek (1995) and Gary \& Monahan (1992) reported that hexanal is a final lipid peroxidation product that is usually recognized as a marker of food quality.

The interaction mechanism between proteins and polyphenols seems to have a non-covalent nature whenever protein molecules are attached together via polyphenolic compounds that act as bridges (Siebert et al., 1996). Further, Ozdal et al. (2013) have reported the consequences of protein-phenolic interactions on the structure and functionality of protein and phenolic compounds under a range of conditions. They reported that the main factors such as temperature, protein type, concentration, $\mathrm{pH}$ and the structure and nature of the phenolic compounds affect interactions of proteins with polyphenols. Damodaran (1996) reported that the extremely complex polymers formed by proteins and polyphenols are fabricated using twenty amino acids. Amino acids are comprised of an amino group, a carboxyl group a hydrogen atom, and side-chain $\mathrm{R}$ groups that are attached covalently to the $\alpha$-carbon atom (Figure 1 ).

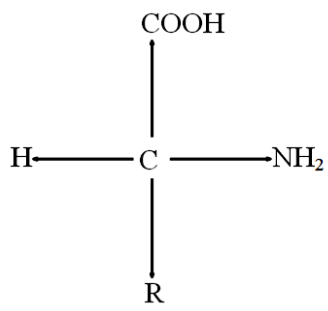

Figure 1 The General Structure of an amino acid

\section{Materials and methods}

\subsection{Materials}

Deuterium oxide $\left(\mathrm{D}_{2} \mathrm{O}\right)$, bovine serum albumin (BSA) lyophilized powder, crystallized $\geq 98.0 \%$ (GE) and cinnamaldehyde liquid (Kosher natural 95\%) were procured from Sigma Aldrich, Poole, UK. Powdered cinnamon was purchased from a local market (Guildford).

\subsection{Methods}

\subsubsection{Sample preparation}

One and a half mg of cinnamon or cinnamaldehyde (500 ppm) was added to $3 \mathrm{~g}$ BSA that was dissolved in $20 \mathrm{ml}$ of $\mathrm{D}_{2} \mathrm{O}$ (15\% BSA).

\subsubsection{FT-Raman spectroscopy}

Samples were placed in $7 \mathrm{~mL}$ glass containers (FBG-Anchor, Cricklewood, London) in a Perkin- Elmer System 2000 FTRaman spectrophotometer with excitation from a Nd: YAG laser at $1064 \mathrm{~nm}$. The instrument was calibrated for frequency using the sulphur line at $217 \mathrm{~cm}^{-1}$. The samples were analysed in triplicate using laser power of $1785 \mathrm{~mW}$. The spectra were an average of 64 scans; the baseline was corrected, scans were smoothed and normalised to the intensity of the phenylalanine band at $1004 \mathrm{~cm}^{-1}$ (Howell et al., 1999; Li-Chan et al., 1994). The spectra were analysed using Grams 32 (Galactic Industries Corp., Salem, NH). Using literature values, assignments of the bands in the spectra to protein vibrational modes were made (Howell et al., 1999; Careche et al., 1999; Li-Chan et al., 1994). Since the intensity of phenylalanine shows a strong band at $1004 \mathrm{~cm}^{-1}$ and it is known to be unaffected by changes in the microenvironment, this band was used as an internal standard for normalisation (Tu, 1986). The results are presented as mean \pm standard deviation for relative peak intensity of the spectra bands.

\subsection{Statistical Analysis}

The mean value and standard deviation were calculated for all experiments. A one-way ANOVA analysis with a Bonferroni test and a Graphpad Prism 6 computer program were used to calculate the differences between the samples in terms of FT-Raman and rheology.

\section{Results and Discussion}

Novel Raman structural markers were anticipated for the tryptophan and histidine side chains by examining the spectrastructure interactions of the model compounds. Raman structure is used to provide information about conformation, hydrogen bonding, hydrophobic interaction, and the ionization of the indole ring of Trp. Figure 2 illustrates the Raman spectrum of BSA alone (black line) in $\mathrm{D}_{2} \mathrm{O}$, BSA mixed with 500 ppm cinnamaldehyde (blue line) in $\mathrm{D}_{2} \mathrm{O}$ and $\mathrm{BSA}$ mixed with $500 \mathrm{ppm}$ cinnamon (red line) in $\mathrm{D}_{2} \mathrm{O}$. It is clear that there are relative intensity changes in many bands and also small shifts in wave numbers. Trp residue is found at the $760 \mathrm{~cm}^{-1}$ band and has been widely investigated (Taukeuich, 2003). 


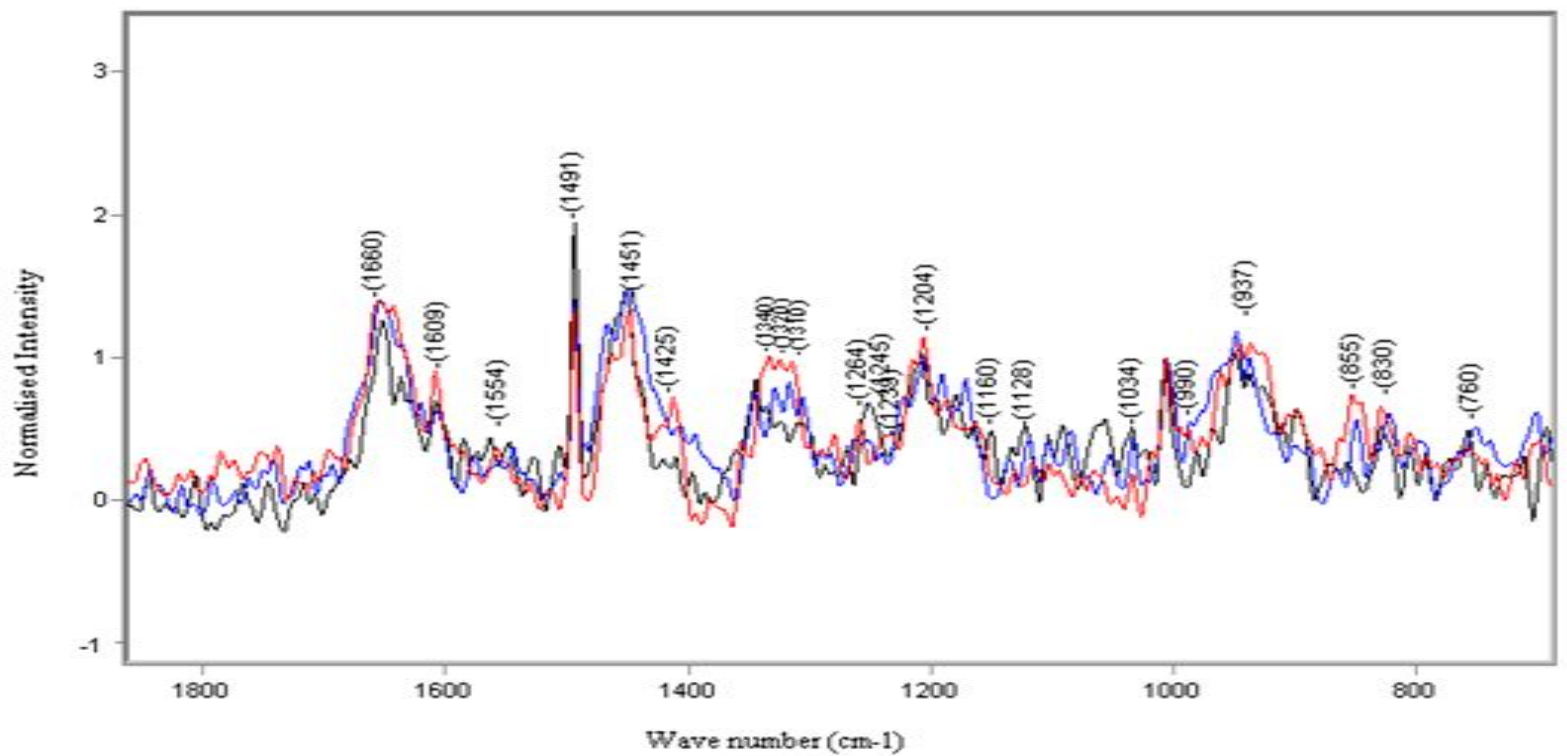

Figure 2 FT-Raman spectra $\left(700-1800 \mathrm{~cm}^{-1}\right)$ of $15 \%$ BSA in $\mathrm{D}_{2} \mathrm{O}$ (black line), $15 \% \mathrm{BSA}+500 \mathrm{ppm}$ cinnamaldehyde in $\mathrm{D}_{2} \mathrm{O}$ (blue line) and $15 \% \mathrm{BSA}+500 \mathrm{ppm}$ cinnamon in $\mathrm{D}_{2} \mathrm{O}$ (red line). Data represent the mean $\pm \mathrm{SD}$.

Trp contains an $\mathrm{N}$ atom, which plays a significant role in hydrogen bonding. The hydrophobic groups and the proton donor site of the indole ring are essential for the interaction with other amino acids. Consequently, any change in amino acids, for instance, lys (lysine), leads to a change in the intensity of the tryptophan band. The intensity of the tryptophan band near $760 \pm$ $2 \mathrm{~cm}^{-1}$ for BSA was found to be $0.42 \pm 0.02$; there was no significant difference between the intensity band of the BSA + cinnamon sample $(0.433 \pm 0.081)$ and BSA. However, for the BSA + cinnamaldehyde sample, the tryptophan intensity band was significantly $(\mathrm{p}<0.05)$ diminished $(0.296 \pm 0.066)$ (Table 1 ; Figure 2). It is quite clear that the cinnamaldehyde treated sample demonstrated a considerable effect (Figure 2). However, the diminishing of the tryptophan band in the cinnamaldehyde sample could be associated with the effect on hydrophobic residues during the interaction.

Figure 3 illustrates the tryptophan band intensities at $760 \mathrm{~cm}^{-1}$ for $15 \%$ BSA, $15 \%$ BSA + 500 ppm cinnamon and 15\% BSA +500 ppm cinnamaldehyde in $\mathrm{D}_{2} \mathrm{O}$. Although the results reveal insignificant band intensity differences between BSA, BSA plus cinnamon and BSA plus cinnamaldehyde, an obvious reduction was noticed in the band for the BSA $+500 \mathrm{ppm}$ cinnamldehyde mixture, compared to the two other samples (Figure 3).

Two strong peaks appeared at 855 and $830 \mathrm{~cm}^{-1}$, revealing the presence of tyrosine. The tyrosine doublet ratios for $15 \%$ BSA, $15 \%$ BSA +500 ppm cinnamon and $15 \%$ BSA +500 ppm cinnamaldehyde in $\mathrm{D}_{2} \mathrm{O}$ are represented in Figure 4. There were slight differences in the tyrosine doublet ratio: $855 / 830$

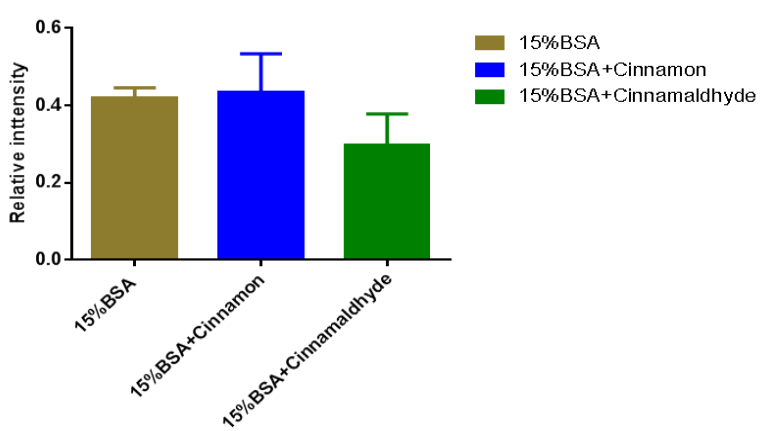

Figure 3 Tryptophan intensity band at $760 \mathrm{~cm}^{-1}$ (Data are expressed as the mean $\pm \mathrm{SD}, \mathrm{n}=3$ )

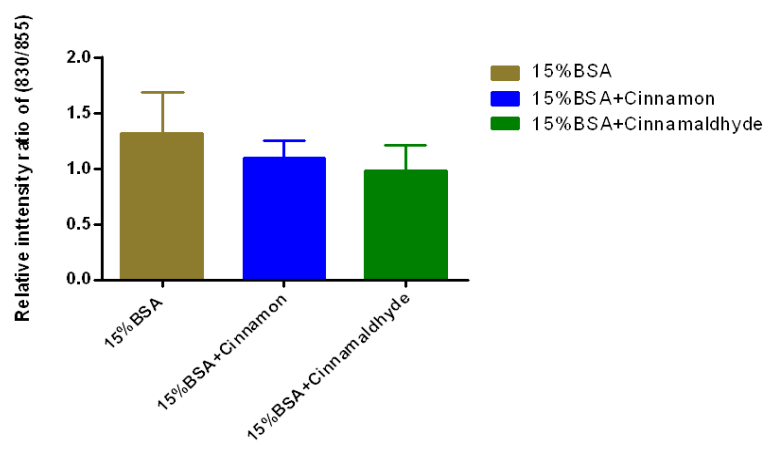

Figure 4 Tyrosine doublet ratio $855 / 830 \mathrm{~cm}^{-1}$ (Data are expressed as the mean $\pm \mathrm{SD}, \mathrm{n}=3$ ) 
Table 1 Relative intensity values (mean \pm SD) in selected regions of the FT-Raman spectra (760-2976 cm-1) of 15\% BSA, $15 \% \mathrm{BSA}+$ cinnamon and $15 \% \mathrm{BSA}+500 \mathrm{ppm}$ cinnamaldehyde.

\begin{tabular}{|c|c|c|c|}
\hline $\begin{array}{l}\text { Assignments and wave } \\
\text { Number }\left(\mathrm{cm}^{-1} \pm 4\right)\end{array}$ & $15 \% \mathrm{BSA}$ & $\begin{array}{l}15 \% \text { BSA+ } \\
\text { cinnamon }\end{array}$ & $\begin{array}{c}15 \% \text { BSA + } \\
\text { cinnamaldehyde }\end{array}$ \\
\hline $\operatorname{Trp}(760)$ & $0.42 \pm 0.02$ & $0.433 \pm 0.081$ & $0.296 \pm 0.066$ \\
\hline Tyr $(830,855) 855 / 830$ & $0.809 \pm 0.22$ & $1.05 \pm 0.18$ & $0.921 \pm 0.12$ \\
\hline Helix C-C stretch, $\mathrm{CH}_{3}$ symmetric stretch (937) & $0.937 \pm 0.051$ & $1.09 \pm 0.024$ & $1.06 \pm 0.075$ \\
\hline$\beta$-sheet type structure (990) & $0.295 \pm 0.013$ & $0.423 \pm 0.064$ & $0.328 \pm 0.053$ \\
\hline Phe, ring band (1034) & $0.522 \pm 0.107$ & $0.197 \pm 0.026$ & $0.318 \pm 0.092$ \\
\hline Isopropyl ant symmetric stretch $\mathrm{CH}$ stretch back bone (1128) & $0.396 \pm 0.011$ & $0.233 \pm 0.02$ & $0.407 \pm 0.087$ \\
\hline $\mathrm{CH}_{3}$ anti symmetric (aliphatic) $\mathrm{CH}_{3}$ rock (aromatic) (1160) & $0.521 \pm 0.062$ & $0.555 \pm 0.024$ & $0.463 \pm 0.039$ \\
\hline$\beta$-sheet type (1239) & $0.349 \pm 0.095$ & $0.487 \pm 0.074$ & $0.388 \pm 0.073$ \\
\hline Amide III (random coil) (1245) & $0.493 \pm 0.091$ & $0.37 \pm 0.034$ & $0.357 \pm 0.063$ \\
\hline Amide III (1264) & $0.343 \pm 0.021$ & $0.608 \pm 0.045$ & $0.474 \pm 0.078$ \\
\hline Amide II (1320) & $0.53 \pm 0.042$ & $1.09 \pm 0.111$ & $0.737 \pm 0.063$ \\
\hline C-H bending doublet from trp (1340) & $0.806 \pm 0.028$ & $1.084 \pm 0.192$ & $0.677 \pm 0.096$ \\
\hline (sh*, residue vibration) asp, glu, lys (1425) & $0.293 \pm 0.026$ & $0.642 \pm 0.081$ & $0.611 \pm 0.09$ \\
\hline Aliphatic groups, CHbend (1451) & $1.421 \pm 0.068$ & $1.574 \pm 0.222$ & $1.261 \pm 0.156$ \\
\hline $\operatorname{Trp}(1554)$ & $0.22 \pm 0.057$ & $0.391 \pm 0.018$ & $0.331 \pm 0.034$ \\
\hline Amide I (1660) & $1.259 \pm 0.063$ & $1.386 \pm 0.117$ & $1.033 \pm 0.22$ \\
\hline CH stretch, aliphatic (2940) & $3.647 \pm 0.144$ & $4.155 \pm 0.256$ & $3.45 \pm 0.326$ \\
\hline Shoulder (2888) & $1.679 \pm 0.155$ & $2.035 \pm 0.035$ & $1.669 \pm 0.141$ \\
\hline $\begin{array}{l}\text { Shoulder (2976) } \\
\text { (2969) }\end{array}$ & $\begin{array}{l}1.51 \pm 0.093 \\
1.833 \pm 0.19 \\
\end{array}$ & $\begin{array}{l}2.113 \pm 0.017 \\
2.426 \pm 0.039\end{array}$ & $\begin{array}{l}1.498 \pm 0.177 \\
1.727 \pm 0.067\end{array}$ \\
\hline
\end{tabular}

Tyr (tyrosine), Trp (tryptophan), Phe (phenylalanine); The spectra were an average of 64 scans baseline corrected, smoothed and normalized to the intensity of Phe band at $1004 \mathrm{~cm}^{-1}$

$\mathrm{cm}^{-1}$ for the BSA solution $(1.321 \pm 0.31)$ as compared with the BSA mixed with cinnamaldehyde and cinnamon $(0.987 \pm 0.19$ and $1.103 \pm 0.13$, respectively (Table 1 and Figure 4). The results show the increased buriedness or linking of tyrosine residues, which are strong hydrogen bond donors in the mixture (Nakai et al., 1994).

In Figure 5 a strong peak at $937 \mathrm{~cm}^{-1}$ ( $\alpha$-helix region) and high $\beta$ sheet content occur in the untreated BSA sample. There was no significant difference $(\mathrm{P}>0.05)$ in peak intensity in the cinnamon- and cinnamaldehyde-treated samples $(1.09 \pm 0.024$ and $1.06 \pm 0.075$, respectively) as compared to $0.937 \pm 0.051$ for BSA only (Figure 5). Similar results were reported by Ngarize et al. (2004) for heated BSA. There was a weak intensity peak at 990 $\mathrm{cm}^{-1}$, representing the beta sheet structure (Figure 2). Table 1 also shows that the non-treated BSA sample's peak intensity at 990 $\mathrm{cm}^{-1}$ was $0.295 \pm 0.013$, which is significantly lower than those of

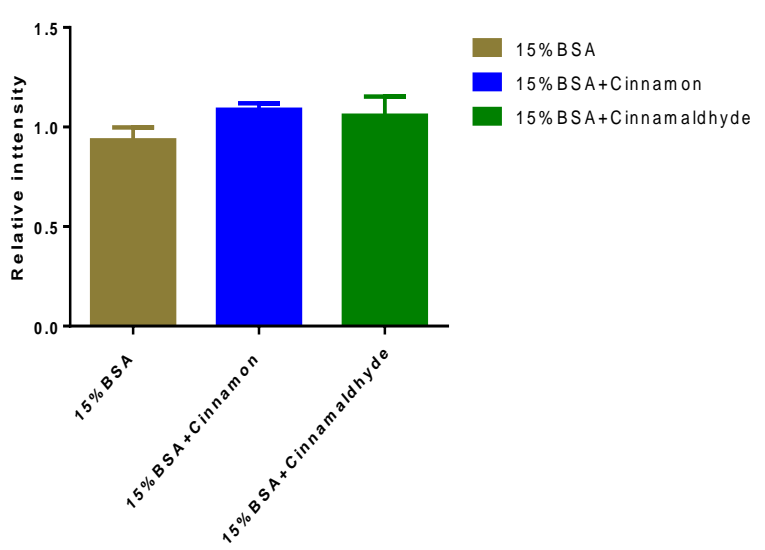

Figure $5 \alpha$-helix regions at $937 \mathrm{~cm}^{-1}$ (Data are expressed as the mean $\pm \mathrm{SD}, \mathrm{n}=3$ ) 


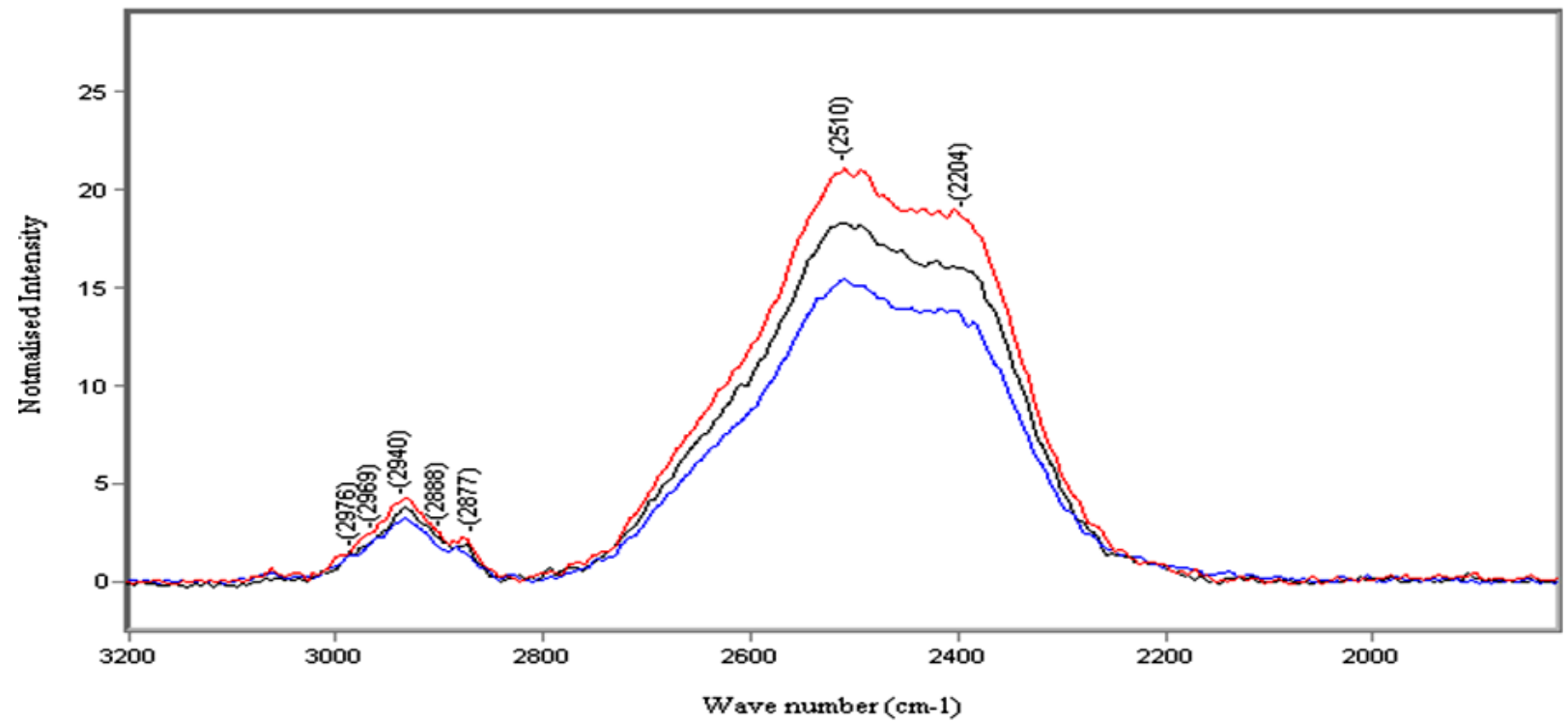

Figure 6 FT-Raman spectra (1800-3200 $\mathrm{cm}^{-1}$ ) of 15\% BSA (black line), 15\%BSA +500 ppm cinnamaldehyde (blue line) and $15 \% \mathrm{BSA}+500$ ppm cinnamon (red line) in $\mathrm{D}_{2} \mathrm{O}$ ( Data represent the mean $\left.\pm \mathrm{SD}\right)$

the cinnamon and cinnamaldehyde treated BSA samples $(0.423 \pm$ 0.064 and $0.328 \pm 0.053$, respectively) $(\mathrm{P}<0.05)$. This increase suggests the existence of anti-parallel $\beta$-pleated sheets (Ngarize et al., 2004). The absence of a peak at $1239 \mathrm{~cm}^{-1}$ was noticed (Figure 2), together with the presence of a peak at $1320 \mathrm{~cm}^{-1}$, indicating greater helical structure content in egg albumen, in agreement with Mine et al., (1990). The band at $1340 \mathrm{~cm}^{-1}$ is due to $\mathrm{C}-\mathrm{H}$ bending from tryptophan. A significant $(\mathrm{p}<0.05)$ decrease in band intensity was noticed in the cinnamaldehyde treated BSA sample $(0.677 \pm 0.096)$ as compared to the untreated BSA sample $(0.806 \pm 0.028)$ (Table 1$)$. This decrease was attributed to the exposure of hydrophobic residues to cinnamaldehyde. A similar result was reported by Ngarize et al. (2004) during the heating of BSA. Also, Badii \& Howell (2002) have reported this drop in peak intensity associated with the aggregate formation of actomyosin in frozen cod and haddock. This finding implies that changes in the hydrophobic environment around the aliphatic and aromatic side chains can be used to screen for denaturation and conformational changes in proteins (Ngarize et al., 2004).

Figure 6 reveals the FT-Raman spectra in the $1800-3200 \mathrm{~cm}^{-1}$ region for $15 \% \mathrm{BSA}, 15 \% \mathrm{BSA}+500 \mathrm{ppm}$ cinnamaldehyde and $15 \% \mathrm{BSA}+500$ ppm cinnamon in $\mathrm{D}_{2} \mathrm{O}$. The broad peak between 2000 and $2600 \mathrm{~cm}^{-1}$ is attributed to $\mathrm{D}_{2} \mathrm{O}$. The $\mathrm{CH}$ stretching band at $2940 \mathrm{~cm}^{-1}$ was assigned to aliphatic amino acids, mainly leucine residues (Howell et al., 1999). The vibrations at (2988 sh, $2976 \mathrm{sh}$ and $2969 \mathrm{sh}$, where sh denotes shoulder) are attributed to the asymmetrical and symmetrical stretching of the $\mathrm{CH}_{3}$ and $\mathrm{CH}_{2}$ groups of the aliphatic chains. The intensities of these bands show a slight increase in the BSA mixture with cinnamon.

Figure 7 shows the intensities of the $\mathrm{CH}$ bending vibrations for $15 \%$ BSA, $15 \%$ BSA + 500ppm cinnamon and 15\% BSA + 500ppm cinnamaldehyde in $\mathrm{D}_{2} \mathrm{O}$. No significant changes in $\mathrm{CH}$ bending were noticed after mixing BSA with cinnamon or cinnamaldehyde antioxidants. However, a slight increase in the $\mathrm{CH}$ bending intensity was noticed in the BSA mixture with cinnamon, while a decrease in the intensity was noticed in the case of the BSA mixture with cinnamaldehyde.

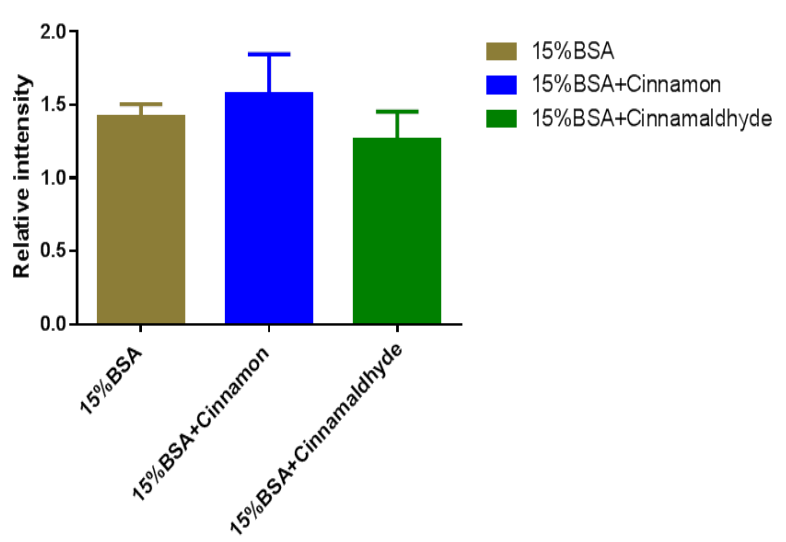

Figure 7 Aliphatic $\mathrm{CH}$ bending vibration at $1454 \mathrm{~cm}^{-1}$ ) (Data are expressed as the mean $\pm S D, n=3$ ) 


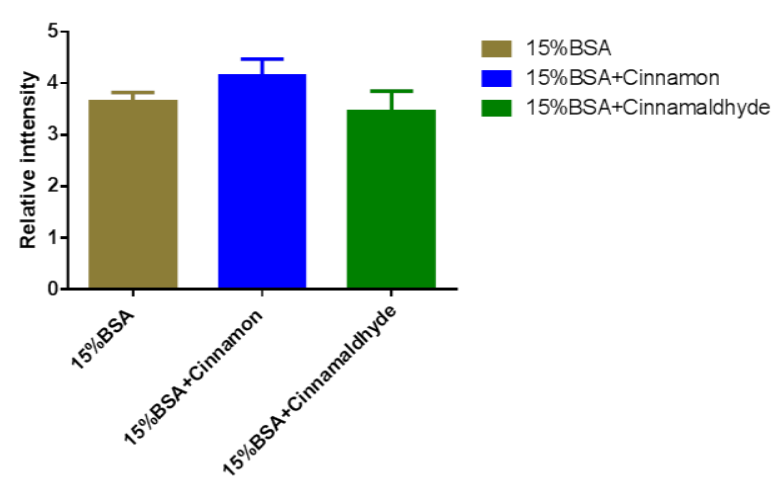

Figure $8 \mathrm{CH}$ stretching vibration at $2940 \mathrm{~cm}^{-1}$ (Data are expressed as the mean $\pm \mathrm{SD}, \mathrm{n}=3$ )

Changes in the $\mathrm{CH}$ stretching band at $2940 \mathrm{~cm}^{-1}$ are represented in Figure 8. No significant changes in the $\mathrm{CH}$ stretching intensity were noticed when comparing BSA and the BSA mixture with either cinnamon or cinnamaldehyde. A slight increase in intensity in the sample treated with cinnamon was noticed, and a drop in the intensity was recorded for the BSA mixture with cinnamaldehyde. Changes in the $\mathrm{CH}$ band stretching follow the same intensity trend change as $\mathrm{CH}$ bending, confirming the active role of cinnamon and cinnamaldehyde in the conformational rearrangements of proteins.

Changes in $\mathrm{CH}$ bending $\left(1450 \mathrm{~cm}^{-1}\right)$ and stretching $\left(2940 \mathrm{~cm}^{-1}\right)$ suggest changes in the aliphatic side chains of BSA proteins. The increase for the cinnamon BSA mixture suggests the participation of aliphatic amino acid residues in hydrophobic interactions (Howell \& Li-Chan, 1996). Similar results have been reported by Howell et al. (2001) when they studied lysozyme-corn oil proteinlipid interactions.

\section{Conclusion}

The study shows that protein-polyphenol (500 ppm cinnamon and cinnamaldehyde) interactions occurred mainly via aliphatic, aromatic and tyrosine amino acids.

\section{Acknowledgements}

Dr. Kamal Alhammad is grateful to Prince Sultan Military Medical City, Riyadh, Kingdom of Saudi Arabia for sponsoring and providing scholarship to pursue his $\mathrm{PhD}$ studies at the University of Surrey, UK.

\section{Conflict of Interest}

Authors would hereby like to declare that there is no conflict of interests that could possibly arise.

\section{References}

Badii F, Howell NK (2002) Effect of antioxidants, citrate and cryoprotectants on protein denaturation and texture of frozen cod (Gadusmorhua). Journal of Agricultural and Food Chemistry 50: 2053-2061

Careche M, Herrero M, Rodriguez-casado C, Del Mazo L, Cannona P (1999) Structural changes of hake (Merluccius L.) fillets: Effect of freezing and frozen storage. Journal of Agricultural and Food Chemistry 47: 952-959.

Damodaran S (1996) Amino acids, peptides, and proteins. In: Food Chemistry, Marcel Dekker, New York, Pp 417-424.

Fogetty C, Witfield B, Svoronos D, Ford L (1989) Effect of heat on the fatty acids and aldehydes of veal meat phospholipids. International Journal of Food Science \& Technology 24: 529-534.

Gary I, Monahan J (1992) Measurement of lipid oxidation in meat and meat products. Trends in Food Science and Technology 3: 315-319.

Howell NK, Li-Chan EC (1996) Elucidation of interactions of lysozyme with whey proteins by Raman spectroscopy. International Journal of Food Science \& Technology 31: 439-451.

Howell NK, Arteaga G, Nakai S, Li-Chan EC (1999) Raman spectra analysis in the $\mathrm{C}-\mathrm{H}$ stretching region of proteins and amino acids for investigation of hydrophobic interaction. Journal of Agricultural and Food Chemistry 47: 924-933.

Howell NK, Herman H, Li-Chan ECY (2001) Elucidation of Protein-Lipid Interactions in a Lysozyme-Corn Oil System by Fourier Transform Raman Spectroscopy. Journal of Agricultural and Food Chemistry 49:1529-1533.

Li-Chan EC, Nakai S, Hirotsuka M (1994) Raman spectroscopy as a probe of protein structure in food systems. In: Yada K, Jackman R, Smith J (Eds.), Protein structure-function relationships in food, Blackie Academic and Professional, London, Pp 185-197.

Nakai S, Li-Chan E, Hirotsuka M (1994) Raman spectroscopy as a probe of protein structure in food systems. In Yada RY, Jackman RL, Smith JL (Eds.), Protein structure-function relationships in Food. Blackie Academic and Professional, London, Pp. 163-197.

Ngarize S, Adams A, Howell NK (2004) Studies on egg albumen and whey protein interactions by FT-Raman spectroscopy and rheology. Food Hydrocolloids 18: 49-59. 
Ozeki M, Miyagawa-Hayashino A, Akatsuka S, Shirase T, Lee W, Uchida K, Toyokuni S (2005) Susceptibility of actin to modification by 4-hydroxy-2- nonenal. Journal of Chromatography B Analytical Technologies in the Biomedical and Life Sciences 827: 119-126.

Ozdal T, Capanoglu E, Altay F (2013) A review on proteinphenolic interactions and associated changes. Food Research International 51:954-970.

Paliyath G, Bakovic M, Shetty K (2011) Functional Foods, Nutraceuticals, and Degenerative Disease Prevention. WileyBlackwell, Oxford, UK.

Refsgaard H, Tasi L, Stadtman E (2000) Modifications of proteins by polyunsaturated fatty acid peroxidation products. Biochemistry 97: 611-614.
Siebert KJ, Troukhanova NV, Lynn PY (1996) Nature of Polyphenol-Protein Interactions. Journal of Agricultural and Food Chemistry 44: 80-85

Takeuchi H (2003) Raman structural markers of tryptophan and histidine side chains in proteins. Biopolymers 72: 305-3 17.

Tu AT (1986) Peptide backbone conformation and microenvironment of protein side chains. In: Clark RJ, Hester RE (Eds.) Spectroscopy of biological systems. John Wiley \& Sons, New York, Pp 47-112.

Uchida K (2003) 4-Hydroxy-2-nonenal: a product and mediator of oxidative stress. Progress in Lipid Research 42: 318-343.

Ulberth F, Roubicek D (1995) Monitoring of oxidative deterioration of milk powder by headspace gas chromatography. International Dairy Journal 5: 523-531 